\title{
Chemotherapy-Associated Pulmonary Toxicity-Case Series from a Single Center
}

\author{
Tilak TVSVGK ${ }^{1, \odot}$ Ajay Handa ${ }^{2}$ Kishore Kumar ${ }^{3} \quad$ Deepti Mutreja $^{4} \quad$ Shankar Subramanian ${ }^{1}$
}

\footnotetext{
${ }^{1}$ Department of Internal Medicine, Armed Forces Medical College (AFMC), Pune, Maharashtra, India

2Department of Medicine, INHS Asvini, Mumbai, Maharashtra, India

${ }^{3}$ Department Medicine, Command Hospital Air Force (CHAF),

Bangalore, Karnataka, India

${ }^{4}$ Department of Pathology, Armed Forces Medical College (AFMC),

Pune, Maharashtra, India
}

\author{
Address for correspondence Tilak TVSVGK, Department of \\ Internal Medicine, AFMC, Pune, Maharashtra, 411040, India \\ (e-mail: drtilaktvs@gmail.com).
}

\section{South Asian J Cancer 2021;10:255-260.}

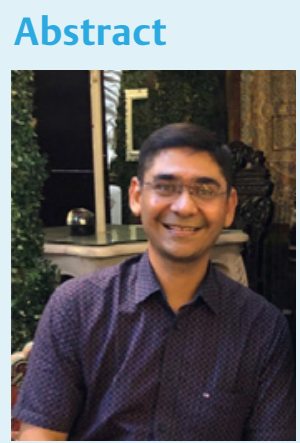

Tilak TVSVGK

Background Pulmonary toxicity due to chemotherapeutic agents can occur with many established and new drugs. Strong clinical suspicion is important as the clinical presentation is usually with nonspecific symptoms like cough, dyspnea, fever, and pulmonary infiltrates. Timely discontinuation of the offending agent alone can improve the condition.

Methods A prospective observational study on patients receiving chemotherapy at an 800-bedded tertiary care hospital was performed from 2014 to 2016. Consecutive patients on chemotherapy, presenting with nonresolving respiratory symptoms were evaluated with contrast-enhanced computerized tomography of chest, diffusion lung capacity for carbon monoxide (DLCO), fiberoptic bronchoscopy with lavage, and biopsy, after excluding all causes for pulmonary infections. Descriptive data has been depicted.

Results A total of 18 patients were evaluated for persistent symptoms of dry cough, dyspnea, and fever among 624 who received chemotherapy during the study period. Ground-glass opacities on high-resolution CT was the most common imaging finding, others being patchy subpleural consolidation and pleural effusion. Lymphocyte-predominant bronchoalveolar lavage was detected in nine. Eight of the 15 patients who underwent DLCO, had abnormal results. Seven had significant histopathological findings on bronchoscopic lung biopsy, which revealed organizing pneu-

Keywords

- chemotherapyassociated pulmonary toxicity

- ground-glass opacities

- transbronchial lung biopsy

- organizing pneumonia monia as the most common pattern. Paclitaxel, fluorouracil, gemcitabine, and tyrosine kinase inhibitors were the common culprit drugs. Discontinuation alone of the culprit drug was effective in 15 and 3 needed oral corticosteroids for relief of symptoms. None of the patients died due to the toxicity.

Conclusion An incidence of $2.8 \%$ for chemotherapy-induced lung injury was seen in our observational study of 3 years, with parenchymal, interstitial, and pleural involvement due to various chemotherapeutic agents. Oral steroids maybe required in a subset of patients not responding to discontinuation of the culprit agent.

DOI https://doi.org/10.1055/s-0041-1731581 ISSN 2278-330X

How to cite this article: TVSVGK T, Handa A, Kumar K, et al. Chemotherapy-Associated Pulmonary Toxicity-Case Series from a Single Center South Asian J Cancer 2021;10(4):255-260. (c) 2021. MedIntel Services Pvt Ltd.

This is an open access article published by Thieme under the terms of the Creative Commons Attribution-NonDerivative-NonCommercial-License, permitting copying and reproduction so long as the original work is given appropriate credit. Contents may not be used for commercial purposes, or adapted, remixed, transformed or built upon. (https://creativecommons.org/licenses/by-nc-nd/4.0/).

Thieme Medical and Scientific Publishers Private Ltd A-12, Second Floor, Sector -2, NOIDA -201301, India 


\section{Introduction}

Chemotherapy-associated pulmonary toxicity is increasingly being recognized as a complication of therapy. The incidence of this toxicity varies from 0.1 to $15 \%$ in various studies. ${ }^{1-6}$ Older drugs as well as novel antineoplastic agents are known to involve lungs in various ways. The clinical manifestations of this entity range from dry cough to sputum production, dyspnea, fever, chest pain, hypoxemia, and respiratory failure. The clinical presentation resembles any pneumonia and hence it needs exclusion in every suspected case. Evaluation of a case likely to have antineoplastic agent-related lung injury requires detailed evaluation of the drug list, markers for drug reaction like eosinophilia and transaminitis, and imaging in the form of high-resolution computerized tomography (HRCT) or contrast-enhanced CT (CECT) scan of the chest. Further evaluation involves study of diffusion lung capacity of lung for carbon monoxide (DLCO), fiberoptic bronchoscopy (FOB) with bronchoalveolar lavage (BAL) and transbronchial lung biopsy (TBLB). The radiological findings are often not very clear on routine chest skiagram. CT scan patterns of involvement include patchy or diffuse ground-glass opacities, reticular or reticulonodular opacities, consolidation areas, or nodules. Common findings on BAL include hypercellularity with neutrophilia or lymphocytosis. The biopsy of lung shows findings of cellular interstitial pneumonitis, eosinophilic inflammatory infiltrates, vasculitis, and organizing pneumonia patterns. ${ }^{1}$

The mainstay of therapy includes discontinuation of the culprit drug and use of corticosteroids for varying duration, guided by clinical response. Alternative agents are usually employed to treat the primary condition. Prompt recognition of this potentially reversible condition is important to prevent disabling morbidity and mortality.

An observational study to detect pulmonary involvement due to chemotherapeutic agents was conducted at a tertiary teaching hospital in South India.

\section{Patients and Methods}

The study was an observational study on patients receiving chemotherapy. The study was conducted at an 800-bedded tertiary teaching hospital with a Malignant Diseases Treatment Centre. The duration of the study was from January 2014 to December 2016. All patients receiving chemotherapy were included in the study and were observed for new-onset respiratory symptoms. They were evaluated to exclude underlying old lung disease, infection, and progression of malignancy. After exclusion of these causes, they were considered to have chemotherapy-induced lung toxicity and treated for the same.

We included consecutive patients on chemotherapyinduced pulmonary toxicity from our center into the study. All patients underwent thorough history and physical examination followed by hemogram and complete biochemical profile. The patients with clinical suspicion of chemotherapy-induced lung toxicity underwent further evaluation with chest radiograph, HRCT or CECT chest, spirometry, DLCO, FOB, BAL fluid examination, and TBLB.

\section{Inclusion Criteria}

1. Patients of malignancy on chemotherapy or targeted therapy.

2. Development of new-onset respiratory symptoms while on chemotherapy or targeted therapy lasting $>48$ hours.

\section{Exclusion Criteria}

1. Patients with preexisting lung disease.

2. Presence of active infection or malignant process involving the lungs.

New-onset respiratory symptoms were defined as cough, dyspnea, or wheeze, which has not responded to symptomatic therapy or persists despite symptomatic therapy for 48 hours. Infective cause and progression of malignancy as a cause for these symptoms was excluded in all cases.

All suspected patients underwent chest radiographs and HRCT of chest (64-slice scanner) and spirometry, and diffusion capacity for carbon monoxide was tested in all cases. Those with abnormal HRCT chest underwent flexible video bronchoscopy performed by a pulmonologist. The morphology of bronchial tree was documented. BAL was obtained using $100 \mathrm{~mL}$ of sterile normal saline. BAL fluid was sent for malignant cytology, differential cytology, Gram stain, fungal stain, acid-fast bacillus stain, and cultures for aerobic bacteria and fungi. TBLB was performed in appropriate cases and sample sent for histopathological examination.

The suspected culprit drug was immediately withheld upon suspecting the diagnosis. Those not responding to cessation of the drug therapy were exhibited oral corticosteroids. Patients were started on alternative drugs for treatment of the cancer, once they recovered and became symptom free.

\section{Results}

\section{Patients and Materials}

A total of 624 patients received chemotherapy or targeted therapy during the study period. Sixty-four patients were noted to have new-onset respiratory symptoms requiring further evaluation or therapy after excluding infection. Eighteen patients had abnormal HRCT chest and underwent further evaluation. Seven patients had demonstrable abnormalities on bronchoscopic lung biopsy.

Eight patients of carcinoma breast on adjuvant therapy and four patients of metastatic carcinoma gall bladder were receiving chemotherapy with weekly paclitaxel. Two patients of metastatic squamous cell carcinoma lung were receiving gemcitabine and one patient of metastatic adenocarcinoma lung was on gefitinib as targeted therapy for epidermal growth factor receptor mutation positivity. One patient of metastatic carcinoma rectum was on 5-flourouracil (5-FU) with leucovorin and oxaliplatin. Two patients of chronic myeloid leukemia (CML) were on dasatinib as a second-line agent. 
The most common symptom was with dry cough, which was not responsive to cough suppressants. Other symptoms included dyspnea on exertion, wheezing, and fever.

All patients underwent routine hemogram and biochemistry including acute phase reactants to exclude active infection precipitating the symptoms. None of the patients had any sign of infection.

\section{Radiology}

Chest X-ray was abnormal in two patients with reticulonodular opacities in lower zones bilaterally. HRCT chest was abnormal in all patients. The common findings included areas of ground-glass opacities, patchy subpleural areas of consolidation suggestive of organizing pneumonia ( - Fig. 1), and bilateral pleural effusion (one case of CML on dasatinib).

\section{Fiberoptic Bronchoscopy}

All patients underwent FOB with BAL and TBLB under topical anesthesia with $2 \%$ lignocaine with monitoring of oxygen saturation and pulse oximetry in the bronchoscopy suite. The patients were given supplemental oxygen by face mask if oxygen saturation was less than $90 \%$ breathing room air. Postprocedure, all patients underwent chest radiograph after 2 hours to look for pneumothorax postlung biopsy. The bronchoscopy showed normal appearance of tracheobronchial mucosa in all the cases. There was hypoxemia in 7 cases during bronchoscopy, which improved with oxygen supplementation during the procedure and resolved in 1 hour postprocedure in all cases.

\section{Diffusion Lung Capacity of Carbon Monoxide}

Spirometry was normal in 3 cases and showed mild restrictive defect in 15 cases. DLCO was tested in 15 cases and showed diffusion impairment in 8 cases, which was mild to moderate (range, $76-54 \%$ predicted).

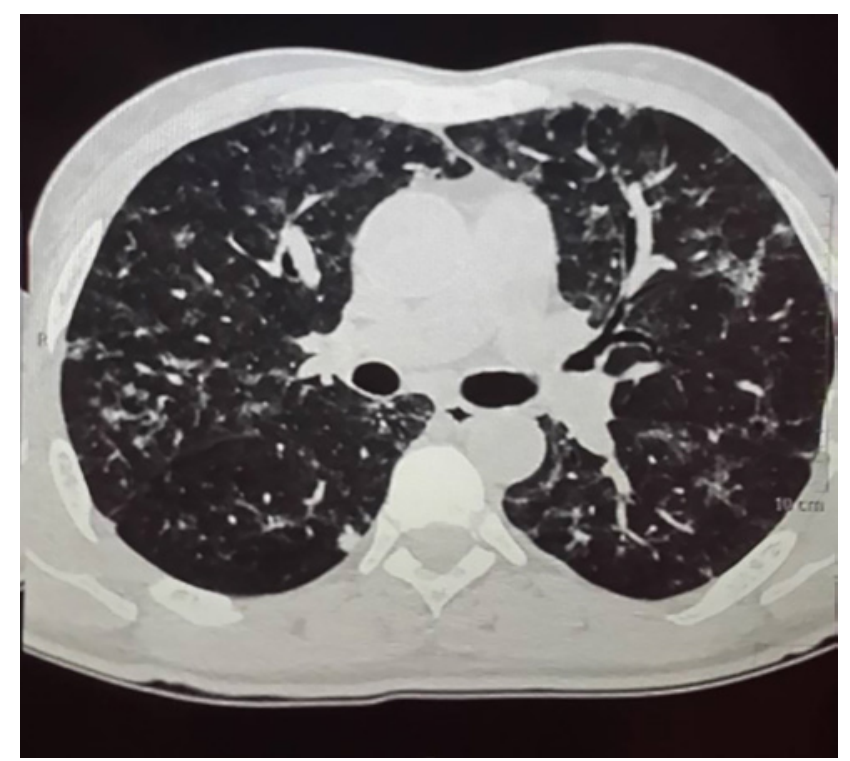

Fig. 1 High-resolution computerized tomography (HRCT) chest shows patchy areas of ground-glass opacities (GGOs) in both lower lobes and few areas of subpleural GGO and nodular lesions (suggestive of organizing pneumonia pattern).

\section{Bronchoalveolar Lavage}

All patients underwent BAL fluid examination for differential cytology. BAL was normal in 9 cases and abnormal in 9 cases, and lymphocytic predominant BAL fluid was the most common pattern. BAL for malignant cytology was negative in all cases. Infective workup and cultures were negative in all cases (details of cytological findings as depicted in - Table 1 ).

\section{Transbronchial Lung Biopsy}

All 18 patients underwent TBLB. The biopsy revealed normal lung tissue in 9 cases, nonspecific chronic alveolar interstitial inflammation in 2 cases, and organizing pneumonia pattern in 5 cases; biopsy yielded inadequate tissue in 2 cases ( - Fig. 2). There were no cases with pneumothorax post-TBLB in this series (details of pathological findings as depicted in - Table 1).

\section{Management and Outcome}

The offending drug was discontinued in all patients. Initial management included use of bronchodilators and cough suppressants. Oral corticosteroids were used for three patients (gefitinib, 5-FU, and dasatinib) for 4 to 8 weeks due to persisting symptoms after drug withdrawal.

There was significant improvement in the symptoms with the management. The patients recovered over a period of 4 weeks. None of the patients were challenged with the culprit drug. Alternate therapies were started for these patients. None of the patients died due to the adverse effect of the culprit drug.

\section{Discussion}

A variety of chemotherapeutic agents can cause histopathologic patterns of lung injury. The incidence of chemotherapy-induced infiltrative pneumonitis is not uncommon but the diagnosis is difficult due to the nonspecific clinical and radiological presentations. ${ }^{1-5}$

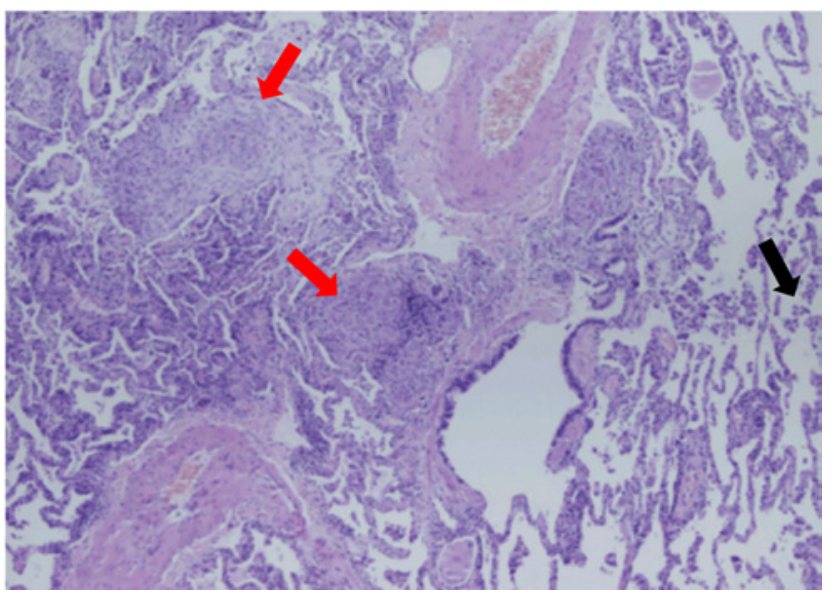

Fig. 2 Hematoxylin and eosin (H\&E), 100× photomicrograph of transbronchial lung biopsy showing areas of normal alveoli (black arrow) and pathologic areas showing patchy filling of alveoli by loose connective tissue plugs (red arrows) suggestive of organizing pneumonia. 
Table 1 Details of patients with chemotherapy-associated pulmonary toxicity

\begin{tabular}{|c|c|c|c|c|c|c|c|c|c|}
\hline S. No. & Age & Gender & Diagnosis & $\begin{array}{l}\text { Drug } \\
\text { used(route) }\end{array}$ & $\begin{array}{l}\text { Schedule/Dose/ } \\
\text { Duration }\end{array}$ & Symptoms & Imaging & BAL & Lung biopsy \\
\hline 1. & 65 & $M$ & $\begin{array}{l}\text { Metastatic } \\
\text { squamous cell } \\
\text { carcinoma lung }\end{array}$ & $\begin{array}{l}\text { Gemcitabine } \\
\text { (IV) }\end{array}$ & $\begin{array}{l}\text { D1 and D8 q 3-weekly / } \\
1000 \mathrm{mg} / 3 \text { months } \\
\text { (3 cycles) }\end{array}$ & $\begin{array}{l}\text { Dyspnea } \\
\text { Dry cough }\end{array}$ & $\begin{array}{l}\text { Organizing } \\
\text { pneumonia }\end{array}$ & $\begin{array}{l}\text { Lymphocyte } \\
\text { predominant }\end{array}$ & $\begin{array}{l}\text { Organizing } \\
\text { pneumonia }\end{array}$ \\
\hline 2. & 56 & M & $\begin{array}{l}\text { Metastatic } \\
\text { carcinoma gall } \\
\text { bladder }\end{array}$ & $\begin{array}{l}\text { Paclitaxel } \\
\text { (IV) }\end{array}$ & $\begin{array}{l}\text { D1, D8, D15 q 4-weekly } \\
\text { / } 150 \text { mg / } 6 \text { months } \\
\text { (6 cycles) }\end{array}$ & $\begin{array}{l}\text { Dyspnea } \\
\text { Dry cough }\end{array}$ & GGO & $\begin{array}{l}\text { Lymphocyte } \\
\text { predominant }\end{array}$ & $\begin{array}{l}\text { Organizing } \\
\text { pneumonia }\end{array}$ \\
\hline 3. & 62 & M & $\begin{array}{l}\text { Chronic myeloid } \\
\text { leukemia }\end{array}$ & $\begin{array}{l}\text { Dasatinib } \\
(\mathrm{PO})\end{array}$ & $\begin{array}{l}\text { Daily / } 70 \text { mg twice a } \\
\text { day / } \\
3 \text { years }\end{array}$ & $\begin{array}{l}\text { Fever } \\
\text { Cough } \\
\text { Dyspnea }\end{array}$ & $\begin{array}{l}\text { Pneumonia } \\
\text { with bilateral } \\
\text { pleural } \\
\text { effusion }\end{array}$ & $\begin{array}{l}\text { Lymphocyte } \\
\text { predominant }\end{array}$ & $\begin{array}{l}\text { Organizing } \\
\text { pneumonia }\end{array}$ \\
\hline 4. & 51 & $F$ & $\begin{array}{l}\text { Carcinoma } \\
\text { breast }\end{array}$ & $\begin{array}{l}\text { Paclitaxel } \\
\text { (IV) }\end{array}$ & $\begin{array}{l}\text { Weekly / } 130 \text { mg / } \\
10 \text { weeks }\end{array}$ & $\begin{array}{l}\text { Dry cough } \\
\text { Dyspnea }\end{array}$ & GGO & $\begin{array}{l}\text { Lymphocytes } \\
\text { predominant }\end{array}$ & $\begin{array}{l}\text { Nonspecific } \\
\text { interstitial } \\
\text { inflammation }\end{array}$ \\
\hline 5. & 52 & M & $\begin{array}{l}\text { Metastatic } \\
\text { adenocarcinoma } \\
\text { lung }\end{array}$ & $\begin{array}{l}\text { Gefitinib } \\
\text { (PO) }\end{array}$ & $\begin{array}{l}\text { Daily / } 150 \mathrm{mg} / \\
09 \text { months }\end{array}$ & $\begin{array}{l}\text { Fever } \\
\text { Dyspnea } \\
\text { Dry cough }\end{array}$ & GGO & $\begin{array}{l}\text { Lymphocyte } \\
\text { predominant }\end{array}$ & $\begin{array}{l}\text { Organizing } \\
\text { pneumonia }\end{array}$ \\
\hline 6. & 54 & M & $\begin{array}{l}\text { Metastatic } \\
\text { carcinoma } \\
\text { rectum }\end{array}$ & $\begin{array}{l}\text { 5-Flourouracil } \\
\text { (IV) }\end{array}$ & $\begin{array}{l}\text { 2-weekly / } 600 \text { mg } \\
\text { (bolus) and } 1000 \mathrm{mg} \\
\text { (22 h CIVI) / } \\
3 \text { months (06 cycles) }\end{array}$ & $\begin{array}{l}\text { Fever } \\
\text { Dyspnea } \\
\text { Dry cough }\end{array}$ & $\begin{array}{l}\text { Patchy } \\
\text { areas of } \\
\text { consolidation }\end{array}$ & $\begin{array}{l}\text { Lymphocyte } \\
\text { predominant }\end{array}$ & $\begin{array}{l}\text { Nonspecific } \\
\text { interstitial } \\
\text { inflammation }\end{array}$ \\
\hline 7. & 52 & $F$ & $\begin{array}{l}\text { Carcinoma } \\
\text { breast }\end{array}$ & $\begin{array}{l}\text { Paclitaxel } \\
\text { (IV) }\end{array}$ & $\begin{array}{l}\text { Weekly / } 120 \text { mg / } \\
11 \text { weeks }\end{array}$ & $\begin{array}{l}\text { Dry cough } \\
\text { Dyspnea }\end{array}$ & GGO & $\begin{array}{l}\text { Lymphocyte } \\
\text { predominant }\end{array}$ & $\begin{array}{l}\text { Organizing } \\
\text { pneumonia }\end{array}$ \\
\hline 8. & 68 & M & $\begin{array}{l}\text { Metastatic } \\
\text { squamous cell } \\
\text { carcinoma lung }\end{array}$ & $\begin{array}{l}\text { Gemcitabine } \\
\text { (IV) }\end{array}$ & $\begin{array}{l}\text { D1 and D8 q 3-weekly / } \\
1000 \text { mg / } 3 \text { months } \\
\text { (4 cycles) }\end{array}$ & $\begin{array}{l}\text { Dry cough } \\
\text { Dyspnea }\end{array}$ & $\begin{array}{l}\text { Subpleural } \\
\text { consolidation }\end{array}$ & Normal & $\begin{array}{l}\text { Inadequate } \\
\text { tissue }\end{array}$ \\
\hline 9. & 56 & M & $\begin{array}{l}\text { Metastatic } \\
\text { carcinoma gall } \\
\text { bladder }\end{array}$ & $\begin{array}{l}\text { Paclitaxel } \\
\text { (IV) }\end{array}$ & $\begin{array}{l}\text { Weekly / } 120 \text { mg / } \\
10 \text { weeks }\end{array}$ & $\begin{array}{l}\text { Fever } \\
\text { Dry cough } \\
\text { Dyspnea }\end{array}$ & GGO & $\begin{array}{l}\text { Lymphocyte } \\
\text { predominant }\end{array}$ & $\begin{array}{l}\text { Inadequate } \\
\text { tissue }\end{array}$ \\
\hline 10. & 42 & $F$ & $\begin{array}{l}\text { Carcinoma } \\
\text { breast }\end{array}$ & $\begin{array}{l}\text { Paclitaxel } \\
\text { (IV) }\end{array}$ & $\begin{array}{l}\text { Weekly / } 120 \text { mg / } \\
10 \text { weeks }\end{array}$ & $\begin{array}{l}\text { Dry cough } \\
\text { Dyspnea }\end{array}$ & GGO & $\begin{array}{l}\text { Lymphocyte } \\
\text { predominant }\end{array}$ & $\begin{array}{l}\text { Unremarkable } \\
\text { lung histology }\end{array}$ \\
\hline 11. & 54 & $\mathrm{~F}$ & $\begin{array}{l}\text { Carcinoma } \\
\text { breast }\end{array}$ & $\begin{array}{l}\text { Paclitaxel } \\
\text { (IV) }\end{array}$ & $\begin{array}{l}\text { Weekly / } 120 \mathrm{mg} / \\
09 \text { weeks }\end{array}$ & $\begin{array}{l}\text { Dry cough } \\
\text { Dyspnea }\end{array}$ & $\begin{array}{l}\text { Patchy alveo- } \\
\text { lar opacities }\end{array}$ & Normal & $\begin{array}{l}\text { Unremarkable } \\
\text { lung histology }\end{array}$ \\
\hline 12. & 52 & $F$ & $\begin{array}{l}\text { Carcinoma } \\
\text { breast }\end{array}$ & $\begin{array}{l}\text { Paclitaxel } \\
\text { (IV) }\end{array}$ & $\begin{array}{l}\text { Weekly / } 120 \text { mg / } \\
12 \text { weeks }\end{array}$ & $\begin{array}{l}\text { Fever } \\
\text { Dry cough }\end{array}$ & GGO & Normal & $\begin{array}{l}\text { Unremarkable } \\
\text { lung histology }\end{array}$ \\
\hline 13. & 44 & $F$ & $\begin{array}{l}\text { Chronic myeloid } \\
\text { leukemia }\end{array}$ & $\begin{array}{l}\text { Dasatinib } \\
(\mathrm{PO})\end{array}$ & $\begin{array}{l}\text { Daily / } 70 \text { mg twice a } \\
\text { day / } \\
6 \text { months }\end{array}$ & $\begin{array}{l}\text { Dry cough } \\
\text { Dyspnea }\end{array}$ & $\begin{array}{l}\text { Bilateral pleu- } \\
\text { ral effusion }\end{array}$ & Normal & $\begin{array}{l}\text { Unremarkable } \\
\text { lung histology }\end{array}$ \\
\hline 14. & 42 & $\mathrm{~F}$ & $\begin{array}{l}\text { Carcinoma } \\
\text { breast }\end{array}$ & $\begin{array}{l}\text { Paclitaxel } \\
\text { (IV) }\end{array}$ & $\begin{array}{l}\text { Weekly / } 120 \text { mg / } \\
09 \text { weeks }\end{array}$ & $\begin{array}{l}\text { Dry cough } \\
\text { Dyspnea }\end{array}$ & $\begin{array}{l}\text { Patchy alveo- } \\
\text { lar opacities }\end{array}$ & Normal & $\begin{array}{l}\text { Unremarkable } \\
\text { lung histology }\end{array}$ \\
\hline 15. & 45 & M & $\begin{array}{l}\text { Metastatic } \\
\text { carcinoma gall } \\
\text { bladder }\end{array}$ & $\begin{array}{l}\text { Paclitaxel } \\
\text { (IV) }\end{array}$ & $\begin{array}{l}\text { Weekly / } 120 \text { mg / } \\
10 \text { weeks }\end{array}$ & $\begin{array}{l}\text { Dry cough } \\
\text { Dyspnea }\end{array}$ & $\begin{array}{l}\text { Patchy } \\
\text { areas of } \\
\text { consolidation }\end{array}$ & Normal & $\begin{array}{l}\text { Unremarkable } \\
\text { lung histology }\end{array}$ \\
\hline 16. & 48 & $F$ & $\begin{array}{l}\text { Metastatic } \\
\text { carcinoma gall } \\
\text { bladder }\end{array}$ & $\begin{array}{l}\text { Paclitaxel } \\
\text { (IV) }\end{array}$ & $\begin{array}{l}\text { Weekly / } 120 \text { mg / } \\
08 \text { weeks }\end{array}$ & $\begin{array}{l}\text { Fever } \\
\text { Dry cough } \\
\text { Dyspnea }\end{array}$ & GGO & Normal & $\begin{array}{l}\text { Unremarkable } \\
\text { lung histology }\end{array}$ \\
\hline 17. & 39 & $F$ & $\begin{array}{l}\text { Carcinoma } \\
\text { breast }\end{array}$ & $\begin{array}{l}\text { Paclitaxel } \\
\text { (IV) }\end{array}$ & $\begin{array}{l}\text { Weekly / } 120 \text { mg / } \\
10 \text { weeks }\end{array}$ & $\begin{array}{l}\text { Dry cough } \\
\text { Dyspnea }\end{array}$ & $\begin{array}{l}\text { Bilateral } \\
\text { Centrilobular } \\
\text { nodules }\end{array}$ & Normal & $\begin{array}{l}\text { Unremarkable } \\
\text { lung histology }\end{array}$ \\
\hline 18. & 57 & $\mathrm{~F}$ & $\begin{array}{l}\text { Carcinoma } \\
\text { breast }\end{array}$ & $\begin{array}{l}\text { Paclitaxel } \\
\text { (IV) }\end{array}$ & $\begin{array}{l}\text { Weekly / } 120 \text { mg / } \\
09 \text { weeks }\end{array}$ & $\begin{array}{l}\text { Dry cough } \\
\text { Dyspnea }\end{array}$ & $\begin{array}{l}\text { Patchy } \\
\text { consolidation }\end{array}$ & Normal & $\begin{array}{l}\text { Unremarkable } \\
\text { lung histology }\end{array}$ \\
\hline
\end{tabular}

Abbreviations: BAL, bronchoalveolar lavage; CIVI, continuous IV infusion; GGO, ground-glass opacities; IV, intravenous; PO, per oral. 
We describe 18 cases of chemotherapy-induced lung toxicity at a single center. All these cases were thoroughly evaluated including lung biopsy to establish the possible pathology. All of them responded to discontinuation of the drug except three who required oral corticosteroids for 4 to 8 weeks. As is true with most cases of drug-induced lung disease, the diagnosis of chemotherapy-induced lung disease can be difficult to confirm. The acute or insidious onset and timing of clinical manifestations associated with chemotherapy-induced lung toxicity is quite variable. It may present during the initial cycle of treatment, after subsequent cycles, or even years later as is the case with carmustine-associated pulmonary fibrosis. ${ }^{14,7,8} \mathrm{~A}$ single chemotherapy agent may be associated with different lung injury patterns. ${ }^{1,7,9,10}$

Fifteen patients had toxicity due to chemotherapeutic agents while three had tyrosine kinase inhibitors as the culprit drug. Paclitaxel was responsible for lung injury in majority of the cases. The average time of onset of respiratory symptoms in these patients ranged from 8 to 11 weeks of therapy. Symptoms due to paclitaxel can develop from hours to weeks after its administration. ${ }^{11}$ Delayed hypersensitivity is the most likely cause of symptoms in patients who present later during therapy. ${ }^{12}$ The radiological abnormalities in these patients included organizing pneumonia in two and one had nonspecific interstitial pneumonia. Contrary to our cases, it is rare for hypersensitivity reactions due to paclitaxel to manifest on HRCT scans. ${ }^{13,14}$

Dyspnea is one of the most common symptoms in patients with chemotherapy-induced lung injury. ${ }^{15}$ Nearly all of our patients had dry cough and dyspnea as the presenting symptoms. Fever was present in six of the patients and no focus of infection was found on complete evaluation.

5-FU and gemcitabine are known to be associated with lung injury and with increased chances of mortality. ${ }^{16,17}$ Our patients on fluorouracil or gemcitabine responded to discontinuation of therapy and steroids.

Small molecules are extensively used in oncology and may cause pulmonary toxicity in a variety of ways. ${ }^{18}$ Dasatinib is a rare cause pulmonary parenchymal injury. ${ }^{19}$ One of the two patients on dasatinib had features of organizing interstitial pneumonia on biopsy while one had only pleural effusion. The time of onset of symptoms due to gefitinib has been reported as 1 to 2 months but our patient developed symptoms after 9 months of therapy. ${ }^{20}$ Off-target effect of gefitinib causing lung injury by Fra-1-related pathway is not shared by erlotinib, despite being the same class of drug. ${ }^{21}$ As a result, erlotinib can be used in patients with gefitinib-induced lung injury, as was done successfully in our case. ${ }^{22,23}$

TBLB can establish the pathology in focal and diffuse parenchymal lung diseases as was seen in our cases. ${ }^{9}$ All our cases underwent TBLB and seven had positive findings on TBLB. Though the histopathological diagnosis is not essential for diagnosing drug-induced lung disease, it helps in excluding other illnesses. ${ }^{24}$

To conclude, chemotherapy-induced lung disease needs a high index of suspicion in patients presenting with dyspnea and cough not responding to symptomatic therapy. This is essential to alleviate the morbidity and mortality associated with drug-induced lung injury. Sequential evaluation with contrast imaging, diffusion lung capacity, bronchoscopy, and biopsy establishes the diagnosis. Majority of cases respond to discontinuation of culprit drug with some needing short course of steroids. Pharmacogenomic studies in future may predict the subset of patients who may develop chemotherapeutic agent-induced lung injury.

\section{Conflict of Interest}

None declared.

\section{References}

1 Vahid B, Marik PE. Pulmonary complications of novel antineoplastic agents for solid tumors. Chest 2008;133(2):528-538

2 Quigley M, Brada M, Heron C, Horwich A. Severe lung toxicity with a weekly low dose chemotherapy regimen in patients with non-Hodgkin's lymphoma. Hematol Oncol 1988;6(4):319-324

3 Skubitz KM, Skubitz AP. Mechanism of transient dyspnea induced by pegylated-liposomal doxorubicin (Doxil) Anticancer Drugs 1998;9(1):45-50

4 Limper AH. Chemotherapy-induced lung disease. Clin Chest Med 2004;25(1):53-64

5 Nakase K, Tsuji K, Nagaya S, et al. Acute interstitial pneumonitis during chemotherapy for haematological malignancy. Eur J Cancer Care (Engl) 2005;14(4):336-341

6 Kim S, Tannock I, Sridhar S, Seki J, Bordeleau L. Chemotherapy-induced infiltrative pneumonitis cases in breast cancer patients. J Oncol Pharm Pract 2012;18(2):311-315

7 Camus P, Bonniaud P, Fanton A, Camus C, Baudaun N, Foucher P. Drug-induced and iatrogenic infiltrative lung disease. Clin Chest Med 2004;25(3):479-519, vi vi.

8 O'Driscoll BR, Hasleton PS, Taylor PM, Poulter LW, Gattameneni HR, Woodcock AA. Active lung fibrosis up to 17 years after chemotherapy with carmustine (BCNU) in childhood. N Engl J Med 1990;323(6):378-382

9 Leslie KO, Gruden JF, Parish JM, Scholand MB. Transbronchial biopsy interpretation in the patient with diffuse parenchymal lung disease. Arch Pathol Lab Med 2007;131(3):407-423

10 Erasmus JJ, McAdams HP, Rossi SE. Drug-induced lung injury. Semin Roentgenol 2002;37(1):72-81

11 Wong P, Leung AN, Berry GJ, et al. Paclitaxel-induced hypersensitivity pneumonitis: radiographic and CT findings. AJR Am J Roentgenol 2001;176(3):718-720

12 Fujimori K, Yokoyama A, Kurita Y, Uno K, Saijo N Paclitaxel-induced cell-mediated hypersensitivity pneumonitis. Diagnosis using leukocyte migration test, bronchoalveolar lavage and transbronchial lung biopsy. Oncology 1998;55(4):340-344

13 Khan A, McNally D, Tutschka PJ, Bilgrami S. Paclitaxel-induced acute bilateral pneumonitis. Ann Pharmacother 1997;31(12):1471-1474

14 Ramanathan RK, Reddy VV, Holbert JM, Belani CP. Pulmonary infiltrates following administration of paclitaxel. Chest 1996;110(1):289-292

15 Sakurada T, Kakiuchi S, Tajima S, et al. Characteristics of and risk factors for interstitial lung disease induced by chemotherapy for lung cancer. Ann Pharmacother 2015;49(4):398-404

16 Shimura $\mathrm{T}$, Fuse $\mathrm{N}$, Yoshino $\mathrm{T}$, et al. Clinical features of interstitial lung disease induced by standard chemotherapy (FOLFOX or FOLFIRI) for colorectal cancer. Ann Oncol 2010;21(10):2005-2010

17 GalvãoFH,PestanaJOM,CapelozziVL.Fatalgemcitabine-induced pulmonary toxicity in metastatic gallbladder adenocarcinoma. Cancer Chemother Pharmacol 2010;65(3):607-610 
18 Saito Y, Gemma A. Current status of DILD in molecular targeted therapies. Int J Clin Oncol 2012;17(6):534-541

19 Radaelli F, Bramanti S, Fantini NN, Fabio G, Greco I, Lambertenghi-Deliliers G. Dasatinib-related alveolar pneumonia responsive to corticosteroids. Leuk Lymphoma 2006;47(6):1180-1181

20 Luo C, Lv M, Li Y, Liu P, Yang J. Gefitinib-induced interstitial pneumonia: a case report and review of the literature. Exp Ther Med 2014;7(4):855-859

21 Takada Y, Matsuo K. Gefitinib, but not erlotinib, is a possible inducer of Fra-1-mediated interstitial lung disease. Keio J Med 2012;61(4):120-127
22 Koma Y, Matsuoka H, Yoshimatsu H, Suzuki Y. Successful treatment with erlotinib after gefitinib-induced interstitial lung disease: a case report and literature review. Int J Clin Pharmacol Ther 2012;50(10):760-764

23 Takeda M, Okamoto I, Makimura C, Fukuoka M, Nakagawa K. Successful treatment with erlotinib after gefitinib-induced severe interstitial lung disease. J Thorac Oncol 2010;5(7):1103-1104

24 Romagnoli M, Bigliazzi C, Casoni G, et al. The role of transbronchial lung biopsy for the diagnosis of diffuse drug-induced lung disease: a case series of 44 patients. Sarcoidosis Vasc Diffuse Lung Dis 2008;25(1):36-45 